\title{
Las i przemysł - układ symbiozy?
}

\author{
Małgorzata Falencka-Jabłońska \\ Zakład Ekologii Lasu, Instytut Badawczy Leśnictwa \\ Braci Leśnej 3, 05-090 Sękocin Stary, falenckm@ibles.waw.pl
}

\begin{abstract}
Streszczenie
Artykuł stanowi podsumowanie ponad 40-letnich wyników ocen i analiz wybranych komponentów biocenoz leśnych i ich skali adaptacji do kumulacji zanieczyszczeń przemysłowych oraz narastającej antropopresji. Problematykę tą przedstawiono na przykładzie oddziaływania na środowisko leśne Puszczy Kozienickiej Elektrowni „Kozienice” (największej w Polsce a od roku i w Europie opalanej węglem kamiennym). Te długoterminowe badania podjęto przed uruchomieniem elektrowni na stałych powierzchniach doświadczalnych IBL i nadal trwa ich kontynuacja, co stanowi ewenement nie tylko w skali naszego kontynentu. Drugi przykład analiz to oceny wieloletniego oddziaływania na ekosystemy leśne Huty Cynku "Miasteczko Śląskie” w Górnośląskim Okręgu Przemysłowym. Na wybranych komponentach biocenoz leśnych omówiono zróżnicowanie zmian różnorodności biologicznej na tle charakterystyk tła zanieczyszczeń oraz wdrażania proekologicznych technologii w dziedzinie ochrony środowiska.
\end{abstract}

\section{Słowa kluczowe}

gradient emisji przemysłowych, różnorodność biologiczna, adaptacja biocenoz leśnych do skażeń środowiska

\section{Wstęp}

„Ochrona zasobów przyrody staje się kierunkiem naukowym i społecznym wskazującym drogi racjonalnego gospodarowania zasobami przyrody. Bierze się tu pod uwagę dobro nie tylko dzisiejszego pokolenia, ale i przyszłych. Ochrona przyrody i jej zasobami nie jest przeciwnikiem produkcji, ale jej sprzymierzeńcem" (Goetel 1966). Słowa te twórcy sozologii, wypowiedziane ponad pół wieku temu, nie straciły swej aktualności, a nawet zyskały szerszy wymiar, z racji wdrażania w rozwoju gospodarczym, zasad zrównoważonego rozwoju.

Antropopresja jest długotrwałym procesem nasilającego się systematycznie wpływu człowieka i jego działalności na otaczającą przyrodę. Szczególnie wyraźnie negatywne skutki oddziaływania przemysłu na środowisko obserwowane są w ciągu ostatnich 200 lat. Dynamiczny rozwój gospodarczy i cywilizacyjny spowodował, że emisje przemysłowe i ich kumulacja zadecydowały o tempie degradacji środowiska, nie tylko na obszarach otaczających zakłady przemysłowe (Falencka-Jabłońska 2006, 2013, 2015, Falencka-Jabłońska, Sobczyk 2017).

Lasy należą do najbardziej złożonych ekosystemów lądowych, stąd też były zawsze czułym indykatorem zakłóceń oraz niekorzystnych zmian środowiska. Warto podkreślić, że pierwsza publikacja dotycząca szkód leśnych, powstałych w wyniku działania emisji przemysłowych na ziemiach polskich, ukazała się w języku niemieckim pod koniec XIX wieku (Reuss 1893). Autor, będąc 
wówczas nadleśniczym obliczył, że terenie nadleśnictwa katowicko- mysłowickiego o łącznej powierzchni 3500 ha, wymierne straty powstałe w wyniku "szkód dymowych” wyniosły aż 200.0oo marek! (Łuczkiewicz 1922a). W cyklu swych artykułów zauważył on również, że im bardziej gatunki drzew są dostosowane do siedliska, tym bardziej odporne na działanie dymów. Jednocześnie domagał się już wówczas objęcia lasów prawną ochroną oraz wydania „ustawy powietrznej”, która określiłaby dozwolone stężenia substancji trujących w powietrzu oraz wskazała skuteczne środki, ograniczające ich powstawanie (Łuczkiewicz 1922).

W latach największej presji emisji przemysłowych na lasy tzn. w latach 70-80. ubiegłego stulecia, oceny strat w przyroście masy drewna oceniano następująco: w I strefie ich oddziaływania to $20 \%$, w II strefie $40 \%$ a w III strefie nawet do $55 \%$. Z kolei w tzw. strefie zerowej szacowano je poniżej $20 \%$. Należy podkreślić również, że przy uwzględnieniu stopnia zadrzewienia straty w przyroście w tych lasach były znacznie większe i tak w: I strefie wielkość ich wynosiła - 25\%, w II strefie $49 \%$ a w III strefie nawet $75 \%$ (Greszta 1975).

Stopień skażenia środowiska był odzwierciedleniem wielkości emitowanych zanieczyszczeń. Dane z połowy lat 8o-tych wskazują, że do atmosfery w naszym kraju trafiało wówczas rocznie ponad $5 \mathrm{mln} \mathrm{t}$ zanieczyszczeń gazowych. Według danych statystycznych GUS wtedy za skażenie to odpowiadało ok. 7 tys. zakładów przemysłowych, a wśród nich 1100 najbardziej uciążliwych za 90\% globalnej emisji. W tej liczbie było 77 zakładów, należących głównie do przemysłu hutniczego, energetycznego i chemicznego, które emitowało wówczas aż 77\% ogólnej emisji gazowej zagrażającej środowisku przyrodniczemu (Rudzki 1985).

Na przełomie XX i XXI wieku polski przemysł wyemitował ok. $3 \mathrm{mln} \mathrm{t} \mathrm{SO}_{2}$, co zadecydowało o niechlubnej czołowej lokacie naszego kraju, wśród państw Europy. Z racji dominującego kierunku wiatrów zachodnich dodatkowo nad nasze terytorium docierało wówczas rocznie z Niemiec i Czech łącznie ok. 1,5 mln $\mathrm{SO}_{2}$ (Falencka-Jabłońska 2013). Aktualne polskie przepisy prawa ochrony środowiska i systematyczne dostosowanie ich do wymogów formalnych obowiązujących w krajach UE oraz uwarunkowania wynikające z ratyfikacji przez Polskę międzynarodowych konwencji, decydują o konieczności systematycznego ograniczenia emisji przemysłowych. Polska podpisując rezolucję 1.2, którą przyjęto w Lizbonie w 1998 r na III Ministerialnej Konferencji nt. Ochrony Lasów w Europie zobowiązała się do prowadzenia gospodarki i polityki leśnej opartych na zasadach zrównoważonego rozwoju.

Zagrożenie lasów oraz obumieranie drzewostanów to efekt choroby łańcuchowej, wywołanej przez czynniki-stresory, które Manion (1981) podzielił na 3 kategorie:

- dyspozycyjne, wywołujące w ekosystemie zmiany mogące doprowadzić do uszkodzenia jego struktury wewnętrznej m.in. klimat - istotne zmiany w składzie chemicznym atmosfery, tzn., że 90\% zawartych w powietrzu substancji kwasotwórczych jest pochodzenia antropogenicznego. Dopływ ilości zanieczyszczeń zwiększył się nawet 10-krotnie.

- $\quad$ wyzwalające, do których należą ekstrema klimatyczne, czyli susze, mróz, znaczne różnice temperatur i wilgotności, wywołujące niedobory tlenu w strefie korzeniowej. Wysokie stężenia zanieczyszczeń oddziaływują również potęgują zakłócenia w funkcjonowaniu ekosystemów.

- towarzyszące, wśród których wiodące to: niedobory substancji odżywczych (np. magnezu), patogeny, grzyby lub owady (Früher 1983).

Wieloletnimi badaniami, rozpoczętymi przez Zakład Ekologii Lasu (wówczas Zakład Ekologii i Ochrony Środowiska) w latach 7o-tych ubiegłego wieku zostały objęte ekosystemy leśne Puszczy Kozienickiej oraz Nadleśnictwa Świerklaniec w GOP-ie, podlegające długotrwałej presji kumulacji imisji przemysłowych. 


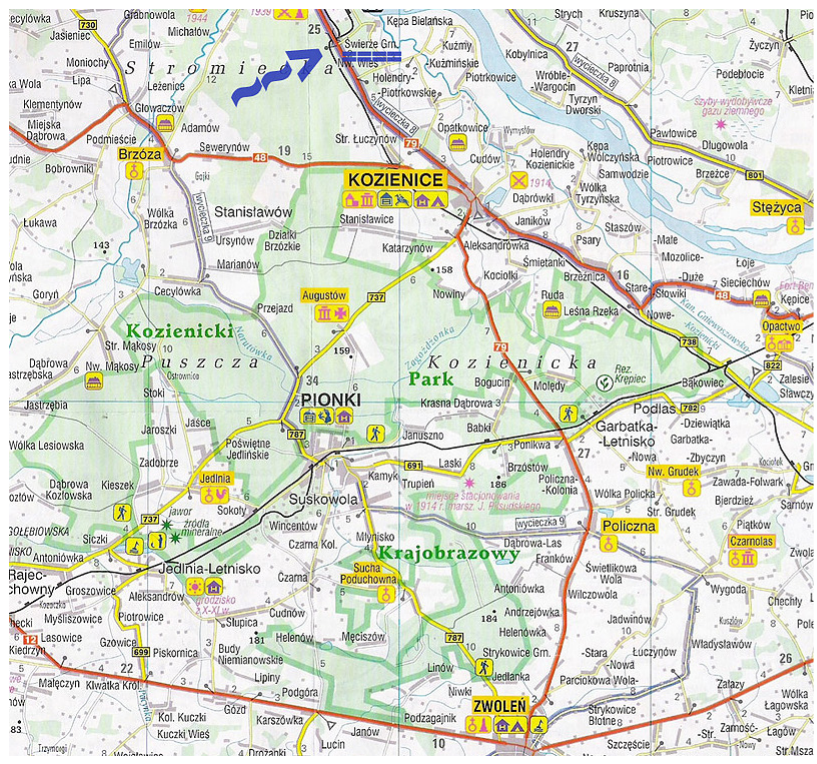

Fot. 1. Mapa z lokalizacją Elektrowni „Kozienice”

\section{Lasy w zasięgu oddziaływania Elektrowni „Kozienice"}

Przedstawiona mapa (fot. 1) ilustruje lokalizację Elektrowni „Kozienice” w Świerżach Górnych, na Równinie Kozienickiej. Jest ona piaszczystą równiną denudacyjną charakteryzującą się urozmaiconym krajobrazem z licznymi wałami, zwanymi na tym terenie „górami”, u podnóża których w zagłębieniach terenu występują gleby bagienne, pokryte wodą, zwane ługami. Średnia liczba opadów rocznie wynosi 500-600 $\mathrm{mm}$, z przewagą opadów wiosennych nad jesiennymi. W ciągu roku występuje tu średnio 150 dni pochmurnych, a dni mroźnych i z przymrozkami jest ok. 155-168 w roku, przy zaleganiu pokrywy śnieżnej 70-8o dni. Okres wegetacyjny trwa tu 210-220 dni.

Budowa Elektrowni rozpoczęła się w 1972 r i trwała 12 lat, w tym czasie w ramach trzech etapów realizacji tej inwestycji oddano do eksploatacji 10 bloków energetycznych o łącznej mocy 2600 MW. Elektrownia „Kozienice” jest największą elektrownią w Polsce, o aktualnej mocy ponad 2700 MGW, opalaną węglem kamiennym. W 2017 roku został przekazany nowy blok o mocy zainstalowanej 1075 MGW blok o najwyższej sprawności na całym świecie. Blok ten będzie miał największą moc w skali Europy.

Celem podjętych badań przyrodniczych, jeszcze przed uruchomieniem Elektrowni, było określenie tempa i kierunków zmian oraz dynamiki przekształceń ekosystemów leśnych, będących pod presją przemysłu. Analizowano dynamikę czynników biotycznych i abiotycznych w ramach interdyscyplinarnych badań, a Elektrownia „Kozienice” stanowi model oceny zmian środowiska leśnego w zasięgu oddziaływania imisji przemysłowych.

Strefy zagrożenia zostały wyznaczone na podstawie modelu rozprzestrzeniania się zanieczyszczeń powietrza, wykonanego we współpracy z Zakładem Ochrony Atmosfery Politechniki Warszawskiej. Strefy te determinowała odległość od emitorów i tak:

- $\quad$ III strefa największego zagrożenia przewidywana była w najbliższym sąsiedztwie emitorów Elektrowni -1,2$3,0 \mathrm{~km}$,

- II strefa średniego zagrożenia w odległości: 6,5-10,o km, 
- I strefa najmniejszego zagrożenia w odległości :15-20 km od emitorów.

\subsection{Materiał i metody}

Bioindykatorem zmian stanu środowiska były porosty. Stanowiły one wskaźnik oceny stopnia zanieczyszczenia środowiska.

W pierwszej fazie badań wpływu oddziaływania na ekosystemy borów we zasięgu oddziaływania Elektrowni „Kozienice” przeprowadzono wstępną rejestrację występowania porostów (Karczmarz 1974). Materiały archiwalne (Karczmarz 1974). były przedmiotem porównań i ocen zmian, które nastąpiły po 34 latach (Kolanko 2007). Wówczas w trzech strefach zagrożenia imisjami Elektrowni „Kozienice” jesienią 2007 r. przeprowadzono ponownie pełną inwentaryzację porostów oraz analizy ich zróżnicowania morfologicznego, taksonomicznego i ekologicznego (Falencka-Jabłońska, Kolanko, Wójcik 2007)

\subsection{Wyniki i wnioski}

Szczegółowe, dwukrotne inwentaryzacje (w pierwszej fazie badań oraz po 34 latach funkcjonowania Elektrowni „Kozienice”) składu gatunkowego i zróżnicowania flory porostów, wykazały interesujące zależności. Mianowicie w III strefie zagrożenia, czyli najbliżej emitorów było ponownie stwierdzonych 5 gatunków w obu terminach, w II strefie 7 gatunków a w I strefie, czyli najdalej od emitorów 6. Jednocześnie najbliżej emitorów odnotowano 15 nowych gatunków porostów, wcześniej tam nieobecnych a w II strefie aż 23, w I strefie zagrożenia 10 gatunków. Co najciekawsze wyniki świadczą, że nastąpił wzrost ogólnej liczby porostów we wszystkich strefach zagrożenia: w III i I ponad dwukrotny a w II strefie aż czterokrotny (tab.1).

Wśród 37 gatunków porostów, których obecność stwierdzono na powierzchniach badawczych, 9 znajduje się na regionalnej Czerwonej liście gatunków zagrożonych w kategoriach EN - 2 gatunki, VU - 2, NT - 4 i LC -1, a tylko 2 na Czerwonej liście porostów wymarłych i zagrożonych w Polsce.
Ochroną ścisłą objętych jest 10 gatunków, a 1 - Cetraria islandica L.Ach. (płucnica islandzka) ochroną częściową (Dz. U. Nr 106 poz. 1167).

Odzwierciedleniem korzystnych zmian zachodzących w środowisku leśnym w zasięgu oddziaływania emisji przemysłowych, jest stwierdzenie obecności niewielkiej populacji Usnea hirta L.Ach. (brodaczka kępkowa) Tworzace ją okazy były prawidłowo wykształcone i nie wykazywały żadnych niekorzystnych zmian morfologicznych Co istotne były również wśród nich i młode osobniki, rozwijające się. Należy podkreślić, że porosty Usnea hirta i Evernia prunastri L.Ach.(mąkla tarniowa) o plechach krzaczkowatych ,wrażliwe na zanieczyszczenia powietrza stwierdzono na powierzchniach badawczych, najbliżej emitorów(III strefa zagrożenia)-Kolanko 2007.

Podkreślić należy, że analizy ponad 27 lat emisji $\mathrm{SO}_{2}$ oraz $\mathrm{NO}_{\mathrm{x}} \mathrm{w}$ przeliczeniu na wyprodukowanie $1 \mathrm{MWh}$ świadczą, że nowoczesne technologie i proekologiczne działania Elektrowni „Kozienice” zdecydowały o istotnym spadku tych emisji gazowych. I tak emisja $\mathrm{SO}_{2} \mathrm{w} 1988 \mathrm{r}$ wynosiła 10, $9 \mathrm{~kg}$, a w ciągu 27 lat spadła do wartości $0,71 \mathrm{~kg}$, czyli 15-krotnie. W analogicznym okresie emisja $\mathrm{NO}_{x}$ przypadająca na wyprodukowanie $1 \mathrm{MWh}$ z 3,27 kg spadła ponad czterokrotnie osiągając wartość $1.04 \mathrm{~kg}$. (rys.1).

Długoterminowe badania prowadzone na stałych powierzchniach często mogą dostarczyć wyjątkowych danych. Do tej kategorii należy na pewno stwierdzenie w trakcie kolejnej inwentaryzacji przyrodniczej w 2009 roku obecności, w odległości ok.120o m od emitorów modliszki zwyczajnej (Mantis religiosa L.). W 2014 r. kolejny przedstawiciel modliszki gościł na składowiskach żużla i popiołu Elektrowni „Kozienice” i został zauważony przez pracownika elektrowni. Należy podkreślić, że tym razem w miejscu, w którym się pojawiła ta zielona piękność, odległość od emitorów, była jeszcze mniejsza niż w 2009 r., bo ok. 600-700 m w linii prostej.W 2015 r. kolejną modliszkę zarejestrowano w II strefie zagrożenia, na terenie 
Tabela 1. Zróżnicowanie gatunków porostów w trzech strefach zagrożenia. Nazwy gatunków zaznaczone kolorem pomarańczowym to te same porosty, tylko inne nazewnictwo. Na niebiesko zaznaczone porosty, które występowały w 1973 r. i w 2007 r., na czerwono zaznaczone porosty, które były w 1973 r., a na zielono porosty, które występowały tylko w 2007 r.

\begin{tabular}{|c|c|c|c|c|c|c|}
\hline \multirow{2}{*}{ Gatunek } & \multicolumn{3}{|c|}{ Strefa (2007 r.) } & \multicolumn{3}{|c|}{ Strefa (1973 r.) } \\
\hline & III & II & 1 & III & II & 1 \\
\hline Cetraria chlorophylla (Willd.) Vain.(pinastris) & & + & . & + & + & . \\
\hline Cetraria islandica (L.) Ach. & & + & . & . & . & . \\
\hline Chaenotheca chrysocephala(Ach.)Th.Fr. & + & + & + & . & . & . \\
\hline Chaenotheca ferruginea (Turner ex Sm.) Mig. & & + & . & . & . & . \\
\hline Cladonia cenotea (Ach.) Schaer. & . & + & . & . & . & . \\
\hline Cladonia chlorophaea (Flörke ex Sommerf.) Spreng. & + & + & + & . & . & . \\
\hline Cladonia ciliata (Stirt.) Harm. var. tenuis (Flörke) Ahti \& Lai & & + & . & . & . & . \\
\hline Cladonia coniocraea auct. & + & + & + & 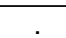 & . & + \\
\hline Cladonia digitata & & . & . & + & . & . \\
\hline Cladonia fimbriata (L.) Fr. & + & + & + & . & . & . \\
\hline Cladonia furcata (Huds.) Schrad. & & + & . & . & . & . \\
\hline Cladonia glauca Flörke & + & + & + & . & . & . \\
\hline Cladonia macilenta Hoffm. & . & + & . & . & . & . \\
\hline Cladonia mitis (SandsT.) Ruoss & . & + & . & . & . & . \\
\hline Cladonia ochrochlora Flörke & . & + & . & . & . & . \\
\hline Cladonia pyxidata (L.) Hoffm. & . & + & . & . & . & . \\
\hline Cladonia rangiferina (L.) Weber in F.H. Wigg. & 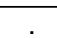 & + & . & & . & . \\
\hline Evernia prunastri (L.) Ach. & + & . & + & . & . & . \\
\hline Graphis scripta (L.) Ach. & & + & . & & & \\
\hline Hypocenomyce scalaris (Ach.) Choisy(Lecidea) & + & + & + & 2.2 & +.1 & 1.2 \\
\hline Hypogymnia physodes (L.) Nyl.(Parmelia) & + & + & + & 3.3 & 1.2 & 1.2 \\
\hline Imshaugia aleurites (Ach.) S.L.F. Meyer (Parmeliopsis) & + & + & + & 2.1 & 1.1 & + \\
\hline Lecanora carpinea (L.) Vain. & & + & . & . & . & . \\
\hline Lecanora conizaeoides Nyl in. Cromb. & + & + & + & & . & . \\
\hline Lecanora expallens Ach. & & + & . & . & . & . \\
\hline Lecanora pulicaris (Pers.) Ach. & + & + & + & . & . & . \\
\hline Lecanora varia (Hoffm.) Ach. & + & . & + & . & . & . \\
\hline Lecidea nylanderi (Anzi) Th.Fr. & + & . & + & & . & . \\
\hline Lepraria incana (L.) Ach. (aeruginosa) & + & + & + & 1.1 & + & 2.1 \\
\hline Melanelia fuliginosa (Fr. ex Duby) Essl. & + & . & . & . & . & . \\
\hline Micarea denigrata (Fr.) Hedl. & + & & . & & . & . \\
\hline Micarea melaena (Nyl.) Hedl. & + & + & . & . & . & . \\
\hline Parmelia sulcata Taylor & + & + & . & & . & \\
\hline Parmeliopsis ambigua (Wulfen in Jacq.) Nyl. & + & + & + & & + & + \\
\hline Placynthiella uliginosa (Schrad.) Coppins \& P.James & & + & + & & & \\
\hline Pseudevernia furfuracea (L.) Zopf (Parmelia) & + & + & + & +.1 & + & 1.2 \\
\hline $\begin{array}{l}\text { Scoliciosporum chlorococcum (Graeve ex Stenh.) Vĕzda } \\
\text { (Bacidia) }\end{array}$ & + & + & + & + & +.1 & + \\
\hline Usnea hirta (L.) Weber ex F.H. Wigg. & & + & + & + & . & . \\
\hline $\begin{array}{l}\text { Liczba gatunków porostów } \\
\text { Number of lichens species }\end{array}$ & 21 & 32 & 19 & 9 & 8 & 8 \\
\hline
\end{tabular}

Nadleśnictwa Dobieszyn, gdzie również zlokalizowane są stale powierzchnie badawcze IBL (Falencka-Jabłońska, Skok-Kurowska 2015).

W 2009 r. i 2014 r. pojawiły się one w tzw. III strefie zagrożenia najbliżej emitorów a w 2015 r. już w II strefie zagrożenia (ok. 7 $\mathrm{km}$ ) od emitorów.
Obecność modliszki nieopodal emitorów Elektrowni „Kozienice” niewątpliwie wskazuje, że dynamika zmian globalnych znajduje swe odzwierciedlenie w reakcji komponentów środowiska lokalnego. Wieloletnie cykliczne badania ekosystemów leśnych, a zwłaszcza zmian różnorodności i bogactwa, wskazują na skalę adaptacji 


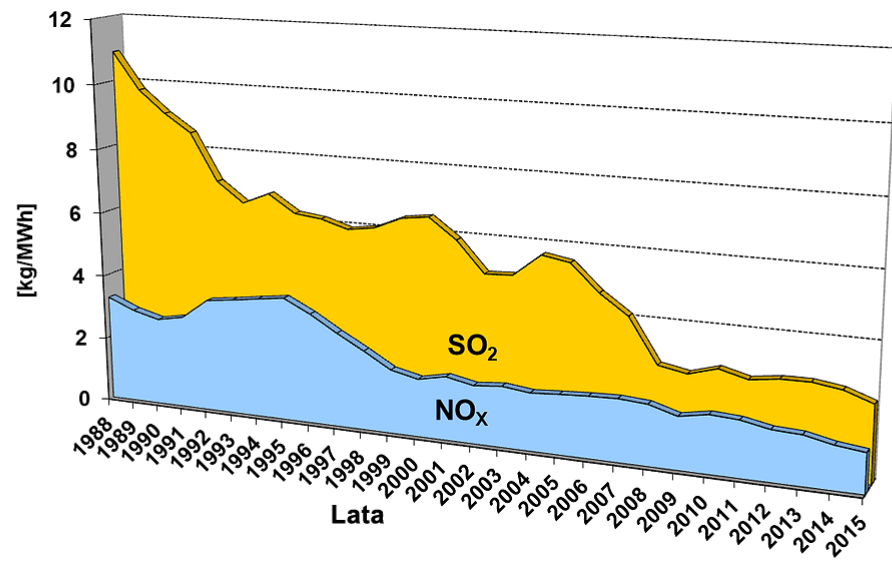

Rys. 1. Zróżnicowanie wielkości emisji gazowych

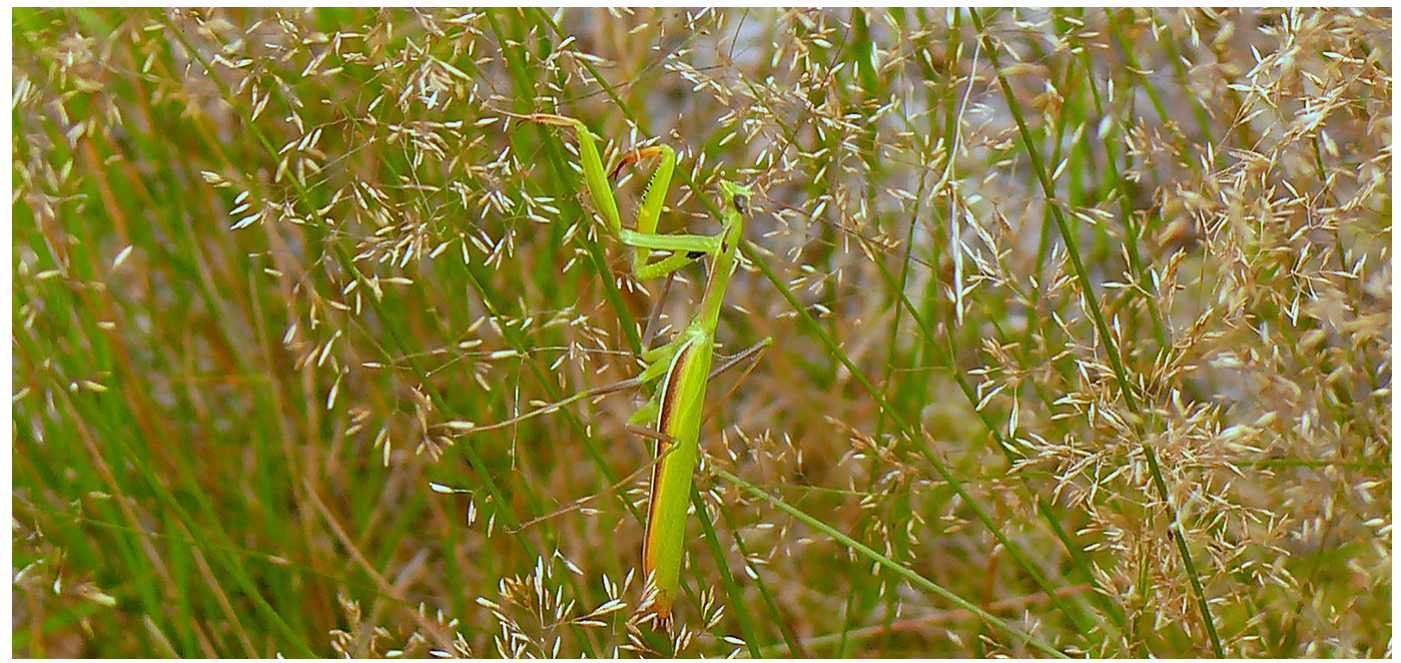

Fot. 2. Modliszka zwyczajna (Mantis religiosa L.)

gatunków i dostosowanie kolejnych faz procesów antropopresji.

Pierwsze informacje o występowaniu modliszki zwyczajnej (Mantis religiosa L.) w Polsce pochodzą z końca XVIII wieku z manuskryptu Karola de Perthéesa, kartografa króla Stanisława Augusta. Wówczas jej obecność stwierdzono w okolicach Warszawy. Od 1923 roku stanowiska modliszki odnotowano głównie w Puszczy Sandomierskiej. W 1938 r. zaobserwowano 5 okazów tego gatunku na terenie lasów Ordynacji Zamojskiej (Leśnictwo Lipa), a w 1947 r. jeden okaz tego gatunku został stwierdzony na
Wyżynie Lubelskiej (Bazyluk 1947). Zgodnie z Witkowskim w Polskiej Czerwonej Księdze (1992) przypuszcza się, że populacja modliszki w naszym kraju rozwinęła się w Polsce dopiero w XX wieku. Według Polskiej Czerwonej Księgi - Zwierzęta bezkręgowe (2004) gatunek ten ma kategorię EN - bardzo wysokiego ryzyka. Szacuje się, że w Polsce populacja modliszki zwyczajnej liczy aktualnie od kilkuset do kilku tysięcy osobników. 


\section{Osobliwości środowisk leśnych w Górnośląskim Okręgu Przemysłowym}

Szczególne miejsce w kategorii terenów zdegradowanych zajmują regiony, gdzie przemysł z racji występowania surowców naturalnych istniał od wieków, a niekorzystny jego wpływ i skutki oddziaływania zakładów, zdecydowały o silnym skażeniu i degradacji środowiska przyrodniczego. Do takich regionów w Polsce należy Górnośląski Okręg Przemysłowy, a na jego terenie obszar Tarnowskich Gór i Miasteczka Śląskiego. Stąd też wyjątkową rangę oraz znaczenie praktyczne mają wyniki wieloletnich, kompleksowych badań prowadzonych od przełomu lat 7o-tych i osiemdziesiątych ubiegłego stulecia przez Zakład Ekologii Lasu IBL (Falencka-Jabłońska 2015, Hawryś 1986).

Jednym z zakładów przemysłowych, istniejących już od 50 lat i mających szczególnie silny wpływ poprzez kumulację imisji na otaczającą przyrodę jest Huta Cynku „Miasteczko Śląskie”. Aktualnie jest ona wiodącym producentem, gdyż ma ona w globalnym bilansie udział na poziomie $40 \%$ cynku i 50\% krajowej produkcji ołowiu i stopów. To o tych terenach twórca teorii pustyni idustriogennej, Janusz Wolak, pisał w końcu lat 60. ubiegłego wieku. „Zmiany industriogenne stają się motorem sukcesji nowych biocenoz dostosowanych do takich warunków. Końcowym etapem tego procesu, przy założeniu stałej koncentracji zanieczyszczeń będzie stadium industrioklimaksu o względnej równowadze i stałości" (Wolak 1969).
Chcąc skutecznie przeciwdziałać negatywnym skutkom emisji przemysłowych oraz ograniczać ich ilość, należy stosować najnowsze technologie służące ochronie środowiska przyrodniczego. Z kolei, prowadzenie badań cyklicznych i wieloaspektowych zmian środowiska przyrodniczego, umożliwia ocenę skali i tempa jego degradacji a ponadto ich wyniki pozwalają dostosować metody rewitalizacji terenów zdegradowanych, do stopnia ich skażenia. Praktycznym przykładem tego typu badań oraz wskazaniem metod oraz sposobów zagospodarowania obszarów podlegających silnej presji wieloletniego oddziaływania imisji Huty Cynku „Miasteczko Śląskie” są aktualnie prowadzone przez Zakład Ekologii Lasu dwuetapowe oceny i analizy (2017/2018). Celem ich jest praktyczne zagospodarowanie tych terenów zdegradowanych.

Skala adaptacji roślinności do tak skrajnie trudnych warunków i ponadnormatywnych stężeń metali ciężkich( kadmu, cynku i olowiu) w glebach (tab.2) jest wyjątkowa. Świadczyć mogą o tym między innymi wyniki inwentaryzacji przeprowadzonej w tzw. strefie śmierci i enklawach leśnych otaczających Hutę Cynku "Miasteczko Śląskie” w czerwcu $2017 \mathrm{r}$.

W strefie najwyższej kumulacji metali ciężkich w glebach, stwierdzono obecność przedstawiciela rodziny storczykowatych-kruszczyka szerokolistnego Epipactis helleborine (L.) CRANTZ. Ogółem odnotowano 25 kwitnących osobników tego gatunku (fot.3). W naszym kraju jest on objęty częściową ochroną. To jedyny europejski

Tabela 2. Analizy fizykochemiczne gleb z poligonu pustyni industriogennej

\begin{tabular}{|l|c|c|c|c|c|r|r|r|r|r|}
\hline & & \multicolumn{2}{|c|}{$\%$} & \multicolumn{9}{|c|}{$\mathrm{mg} / \mathrm{kg}$} \\
\cline { 3 - 12 } Nr ewid. & $\mathrm{pH} \mathrm{KCl}$ & $\mathrm{C}_{\text {org. }}$ & $\mathrm{N}_{\text {og. }}$ & $\mathrm{Mn}$ & $\mathrm{Cu}$ & $\mathrm{Pb}$ & $\mathrm{Cd}$ & $\mathrm{Zn}$ & $\mathrm{Cr}$ & $\mathrm{Ni}$ \\
\hline $33 \mathrm{a}$ & 7,2 & 0,52 & 0,022 & 476,5 & 926 & 5080 & 340,9 & 6914 & 72,20 & 22,14 \\
$33 \mathrm{~b}$ & 6,2 & 0,20 & 0,018 & 312,5 & 30,8 & 231 & 7,5 & 401 & 6,38 & 4,59 \\
\hline $34 \mathrm{a}$ & 6,7 & 0,85 & 0,048 & 292,4 & 40,9 & 2212 & 180,4 & 2801 & 9,18 & 6,92 \\
$34 \mathrm{~b}$ & 6,7 & 0,34 & 0,029 & 243 & 21,7 & 782 & 34,6 & 1108 & 5,95 & 4,61 \\
\hline $35 \mathrm{a}$ & 5,9 & 1,25 & 0,078 & 451,2 & 21,2 & 948 & 101,9 & 2289 & 10,64 & 6,84 \\
$35 \mathrm{~b}$ & 6,8 & 0,80 & 0,031 & 449,9 & 23,6 & 1134 & 38,4 & 1496 & 17,12 & 12,97 \\
\hline
\end{tabular}




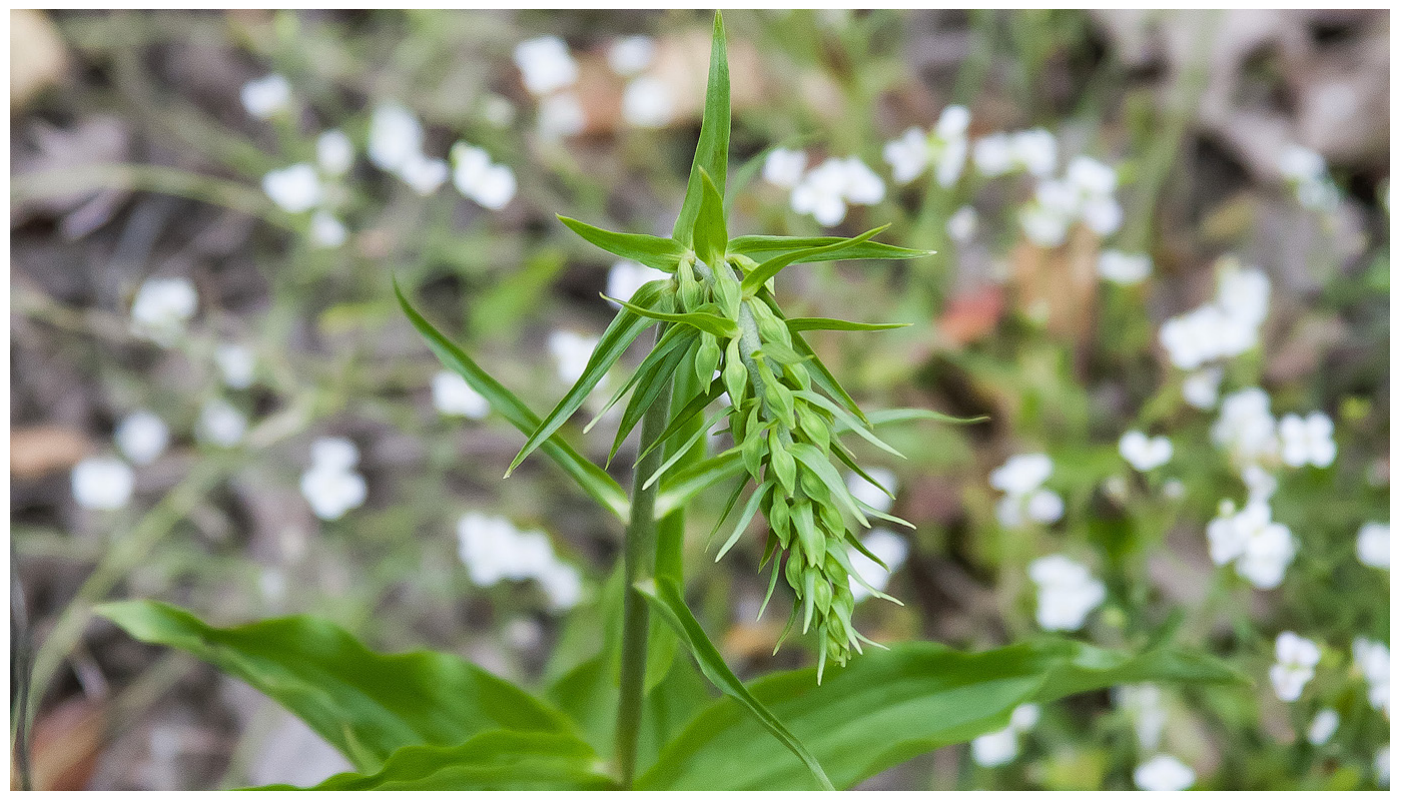

Fot. 3. Kruszczyk szerokolistny Epipactis helleborine (L.) CRANTZ

gatunek storczykowatych, który został zawleczony do Ameryki Północnej (1879 r.).

W Polsce występuje on często i charakteryzuje się szeroka amplitudą ekologiczną. Spotkać go można zarówno w żyznych buczynach jak i w ubogich borach sosnowych oraz na wydmach. Gatunek ten wykazuje również silne zdolności do przenikania na stanowiska półruderalne tzn., że notowany jest na terenach znacznie przekształconych antropogenicznie, np. w opuszczonych ogrodach, na podmiejskich nieużytkach, a nawet na hałdach kopalnianych. Jest to roślina miododajna i owadopylna, zapylana najczęściej przez błonkówki, nierzadko też dochodzi do samozapylenia. Kwitnie od czerwca do września. Nektar jego kwiatów zawiera związki chemiczne o narkotycznym działaniu na owady. Wywołuje ono spowolnienie ich reakcji, wydłużając tym samym czas spędzany przez nie na kwiatach kruszczyka, mimo ich małej atrakcyjności. To „zabezpieczenie", którym obdarzyła je natura gwarantuje kruszczykom tak ważne w procesie ich przetrwania, zapylenie kwiatów.

Jednocześnie zaobserwowano, że w enklawach, gdzie utrzymały się sosny to cechowała je zdecydowana „walka” o przetrwanie.
Przejawem jej jest charakterystyczne, wyjątkowo obfite wytwarzanie licznych szyszek, nawet na najniższych gałęziach, często leżących bezpośrednio na piaszczystym podłożu.

\section{Bibliografia}

Falencka-Jabłońska M. 2006. Synteza 3o-letnich kompleksowych analiz wpływu Elektrowni „Kozienice" na środowisko leśne w monografii, w: Ochrona powietrza w teorii i w praktyce, tom II, Konieczyński J. (red.), Inst. Podst. Inż. Śr., Zabrze, 67-78.

Falencka-Jabłońska M. (red.). 2013. Zmiany ekosystemów leśnych w zasięgu oddziaływania Elektrowni "Kozienice” -synteza 4o-letnich badań interdyscyplinarnych. Prace IBL, Rozprawy i Monografiezo.

Falencka-Jabłońska M. (red.). 2015. Wpływ imisji przemysłowych na strukturę lasów i zmiany komponentów środowiska - synteza 4o-letnich badań w Górnośląskim Okręgu Przemysłowym Prace IBL, Rozprawy i Monografie 21.

Falencka-Jabłońska M., Kolanko K., Wójcik J. 2007. Różnorodność biologiczna jako wskaźnik adaptacji ekosystemów leśnych w zrównoważonym zagospodarowaniu lasu w zasięgu oddziaływania Elektrowni „Kozienice” S.A. Dokumentacja IBL, Sękocin. 
Falencka-Jabłońska M., Sobczyk W. 2017. Rozwój zrównoważony a ochrona przyrody Edukacja Technika Informatyka, 1(19), 139-144.

Greszta J. 1975. Wpływ imisji na siedliska borowe i drzewostany sosnowe w Śląsko-Krakowskim Okręgu Przemysłowym. Zakład Ochrony Przyrody PAN, PWN Warszawa-Kraków.

Hawryś Z. 1986. Ustalenie zestawu gatunków drzew i krzewów przydatnych do zalesień znajdujących się pod wpływem emisji przemysłowych. Dokumentacja IBL.

Kolanko K. 2007. Ocena stanu zanieczyszczenia środowiska wybranych powierzchni Puszczy Kozienickiej na podstawie analizy składu wybranych gatunków porostów - sprawozdanie etapowe, IBL, Warszawa.

Łuczkiewicz W. 1922a. Kilka słów o szkodach dymowych w okolicy Katowic, Sylwan, VIII-IX, 195-198,
Łuczkiewicz W. 1922b. Wpływ dymów fabrycznych na drzewostany, Sylwan, IV, 84-87.

Łuczkiewicz W. 1922c. Wpływ dymów fabrycznych na drzewostany, Sylwan, V, 103-106.

Łuczkiewicz W. 1922d. Wpływ dymów fabrycznych na drzewostany, Sylwan, VII, 160-164.

Manion P.D. 1981. Tree disease concepts. Prentice Hall Ins. Eglewood Cliffs, Nd, 199.

Reuss C. 1893. Rauchbeschandigung in dem von Tiele Winklerschen Forstrevier Myslowitz /Katowitz.

Rudzki K. 1985. Czy stać nas na dalsze niszczenie lasów?- referat w ramach posiedzenia Rady NOT oraz Stowarzyszenia Inżynierów i Techników Drzewnictwa, grudzień, Warszawa.

Wolak J. 1969. Industrioklimaks nowe pojęcie w teorii sukcesji, Ekol.pol.ser.B, XV,1: 41-44.

\title{
Forest and industry - a symbiosis system
}

\begin{abstract}
The article is a summary of over 40 years' results in assessment and analysis of chosen components of forest biocoenosis and their adaptation to the accumulation of industrial pollution and growing anthropopressure. These issues were presented in the example context of the impact of the 'Kozienice' Power Plant, which is fired with bituminous coal, on the environment of the Kozienice Forest (the largest forest in Poland and, since last year, also in Europe). Those long-term studies were undertaken on permanent experimental areas of the Forest Research Institute before the establishment of the power plant and are still being continued what is a sensation not only on continent level. The second analysis example is the assessment of the long-term impact of Huta Cynku 'Miasteczko Śląskie' in the Upper Silesian Industrial Region. Among the discussed components of forest biocoenosis was the differentiation of changes in biodiversity against the backdrop of pollution characteristics and the introduction of pro-ecological technologies in the forest protection field.
\end{abstract}

\section{Keywords}

gradient of industrial emission, biodiversity, forest biocoenoses adaptation to contamination of environment 